\title{
Environmental change and social conflict: the northeast Atlantic mackerel dispute
}

\author{
Jessica Spijkers $^{1}$ (D) $\cdot$ Wiebren J. Boonstra ${ }^{1}$
}

Received: 30 March 2016 / Accepted: 26 March 2017 /Published online: 18 April 2017

(C) The Author(s) 2017. This article is an open access publication

\begin{abstract}
A recurrent critique of the proposition of a causal relation between environmental change and social conflict is that it fails to account for the complexities and dynamics of processes of social-ecological change. In this article, we open the black box of contextual factors that influence the causal pathway from environmental change to social conflict. Firstly, we argue for the consideration of three social factors that influence that pathway: (a) institutions, (b) power, and (c) knowledge. Taking a deductive approach, we ascertain their causal importance in the case of the "mackerel dispute," an interstate conflict that unfolded after the abrupt and rapid change in distribution of the northeast Atlantic mackerel stock after 2007. We analyze the historical development of the mackerel dispute through process tracing and demonstrate the importance and causal role of the three factors. Secondly, based on our assessment, we argue to increase the diversity of the scope conditions relevant for the environmental changesocial conflict nexus. We propose to consider a wider variety of conflicts as outcome of environmental change, highincome regions as an arena for those conflicts, and a wider variety of environmental change, such as alterations in abundance in the context of climate change. Lastly, we discuss how future research on this topic can handle the wider scope conditions and greater case variability.
\end{abstract}

Keywords Environmental change $\cdot$ Conflict $\cdot$ Northeast Atlantic mackerel $\cdot$ Power $\cdot$ Institutions $\cdot$ Knowledge

\section{Editor: Will Steffen}

Jessica Spijkers

jessica.spijkers@su.se

1 Stockholm Resilience Centre, Stockholm University, Stockholm, Sweden

\section{Introduction}

That environmental change can lead to social conflict has been witnessed many times during human history (Cullen et al. 2000; Zhang et al. 2007; Haug et al. 2003; Yancheva et al. 2007; Burke et al. 2015). The idea behind all these observations is well-rehearsed: changes in environmental conditions - the quantity and quality of natural resources - can trigger stress and conflict between individuals and groups that depend on these resources for their livelihood, sometimes even leading to violence and war. A recurrent critique of the proposition of a causal relation between environmental change and social conflict is that it fails to account for the complexities and dynamics of processes of social-ecological change. It is not often that environmental change alone leads to conflict; "it always interacts with other political, economic, and social factors" (Homer-Dixon 1999, p. 178; see also Brundtland 1987; Elliott 1996). With this in mind, the relation between environmental change and social conflict appears far from straightforward, but rather represents a "nexus" with an underlying social-ecological causality that is complex and dynamic (Homer-Dixon 1996, 1991; Elliott 1996). Unraveling this nexus creates a dilemma. To render propositions more realistic and empirically useful, we need to better account for contextual conditions and diversity. Yet, all-inclusiveness will inevitably lower generalizability.

To improve contextual knowledge of the "environmental change-social conflict nexus," this paper introduces three social factors that influence the causal pathway from environmental change to social conflict. These factors include (a) institutions, (b) power, and (c) knowledge. All have great explanatory value in social science theories, which means that they likely will be influential in cases where a causal relation between environmental change and social conflict exists. Additionally, to render propositions more realistic and valid, 
this paper also suggests broadening the consideration of socalled scope conditions, i.e., conditions under which (theoretical) propositions about causality between environmental change and social conflict would hold.

This paper proceeds as follows. It will first review the debate about the environmental change-social conflict nexus and explain why it is plausible to include institutions, power, and knowledge as important social factors. It will then demonstrate the importance and causal role of these factors with a case study of the abrupt and rapid change in the distribution of the northeast Atlantic mackerel stock after 2007. This shift in distribution meant that the northeast Atlantic mackerel became more abundant in northern Atlantic waters, which in turn triggered an interstate conflict over the size and allocation of fishing quotas between the European Union (EU), Norway, Iceland, and the Faroe Islands.

The case of the northeast Atlantic mackerel dispute is instrumental considering the objectives of this paper, because it first of all illustrates the workings of the social factors that we identified earlier. Second, the case also illustrates what happens if the conditions for the environmental change-social conflict nexus widen, because the mackerel dispute has until now never been used to theorize on the "environmental change-social conflict nexus." This is surprising because in fisheries and marine sciences, the conflict has the status of a "paradigm case" (Flyvbjerg 1998) that demonstrates the impact of climate fluctuations on fish populations, fishers, and conflicts over marine resources (Sumaila et al. 2011; Pinsky and Fogarty 2012). Although the precise causes behind the mackerel shift remain to be fully understood, the mackerel case holds up as an empirical example of a process of global environmental change that will manifest itself more pronounced and widely in the decades to come. Marine scientists anticipate large-scale changes in distribution and productivity of marine organisms under the influence of ocean warming (Cheung et al. 2010; Gattuso et al. 2015), which are expected to increase the potential for international conflict over marine resources, impeding effective and sustainable marine governance (Miller 2000). Accepting the mackerel case as an instructive case will significantly increase the population of potential cases relevant to exhibit causality between environmental change and social conflict. We end the paper with a discussion of how future research on this topic can handle the wider scope conditions and greater case variability.

\section{From environmental change to social conflict: causal mechanisms}

To begin, we need to reflect on the meaning of the term nexus in this discussion as it is used in multiple and ambiguous ways (Cairns and Krzywoszynska 2016). We use the term as an analytical concept to theorize the various mediating factors that influence the causal pathway linking environmental change to social conflict. Theorizing and investigating these causal pathways is a key objective in sustainability science. Scholars in this field emphasize that causal pathways between ecology and society are typically complex, adaptive, non-linear, cross-scale, and volatile (Boyd and Folke 2012; Galaz 2014; Folke et al. 2005; Fraser et al. 2003; Olsson et al. 2007).

In line with this train of thought, the environmental change-social conflict nexus can be said to consist of INUS causes. INUS stands for "an insufficient but necessary part of a condition which is itself unnecessary but sufficient for the result" (Mahoney et al. 2009: 125). INUS causes are thus by themselves neither necessary nor sufficient, but form part of a large combination of causes that together are sufficient to produce the outcome under scrutiny (Mahoney et al. 2009). Situations explained through INUS causes are characterized by low proximity (many intervening variables between cause and effect), high multi-causality (many variables operating together to produce the outcome), interactivity (none of the causes alone is sufficient to produce the outcome), and non-linearity (a process exhibiting threshold effects) (Homer-Dixon 1996).

As has been explained in the "Introduction," there is a need to explore the scope conditions under which a causal pathway between environmental change and social conflict exists, and to include more intervening variables in the explanation. This poses a formidable challenge because processes produced from INUS causes can include a wide range of variables and interactions. Consequently, it is difficult to know which variables to include, or to know how the selected variables function in a causal process (Homer-Dixon 1996).

For these situations, when it is impossible to control for variables, several scholars (e.g., Geertz 1963; Homer-Dixon 1996) have proposed to rely on process tracing as a methodological tool. According to George and Bennett (2005: 206), process tracing "attempts to identify the intervening causal process - the causal chain and causal mechanism - between an independent variable (or variables) and the outcome of the dependent variable". Crucial here is that it aims to identify the intervening variables or "causal mechanisms" (Mahoney 2001) between an initial cause (environmental change) and final outcome (social conflict).

To know which intervening variables are modulating the causal pathway from environmental change to social conflict, this paper proposes to deductively identify factors that can be assumed relevant (see also Homer-Dixon 1999: 80). The three factors that we identified - institutions, power, and knowledge - represent categories of causal mechanisms which are frequently used to explain social action. Social causal mechanisms have been selected because these are often identified as intervening factors when it comes to adjusting to processes of environmental change (Garmestani and Allen 2015; Chaffin 
et al. 2014; Folke et al. 2007; West 2016). The next section introduces the three social factors, their respective literatures, and the reasons why they were selected.

\section{Institutions}

Institutions refer to "regulative, normative, and culturalcognitive elements that provide stability and meaning to social life" (Scott 2013: 56). These elements can include not only social structures and symbolic meanings but also legislation. Institutions facilitate the reproduction of social life and for this reason provide society with "solidity across time and space" (Giddens 1984: 24). Various sustainability scholars have pointed out the crucial role of institutions in shaping the ways in which human society interconnects with natural environments. Interconnections which they often conceptualize as a "mismatch" (Folke et al. 1998; Cumming et al. 2006; Olsson et al. 2007; Galaz et al. 2008; Ekstrom and Young 2009; Ernstson et al. 2010; Termeer et al. 2010; Cumming et al. 2013; Bergsten et al. 2014) to draw attention to the degree of compatibility between natural environments and the institutional arrangements that manage human activities affecting these environments (Young 2002). When that compatibility is waning or poor, the "institutional jurisdiction [is] unable to cope with actors or drivers external or internal, and important for maintaining the ecosystem(s) or process(es) affected by the institution" (Galaz et al. 2008: 150). Many examples exist where institutions fail to accommodate and adjust to environmental change (Olsson et al. 2006, 2007) or the inherent complexity of ecosystems (Brundtland 1987).

\section{Power}

It is a well-established view that power is a major determinant of social interaction (Russell 1938 [1939]). The concept power always refers to social power and intends to capture the abilities that allow humans to influence the conduct of others and the contexts in which these others are situated. Recently, it has been argued that the term "others" not only does refer to other humans but also includes non-anthropogenic entities (Stone-Jovicich 2015), and that "contexts" refers to both social and environmental contexts (Boonstra 2016). In this paper power is operationalized as 'balances of power' as introduced by the sociologist Norbert Elias. Power balances refer to the differentials (ratios or distributions) in the chances that people have to influence the outcomes of social and ecological interactions (Elias 2012 [1970]: 69-89, 111, 152; see also Goudsblom 2001: 45-59).

\section{Knowledge}

To understand why people behave the way they do, one needs to consider the ways in which they know their conditions and themselves (Weber 1978). Knowledge serves as a tool through which humans give meaning to the world, and which motivates their actions. The effect of knowledge becomes especially clear in times when social or ecological conditions are unexpectedly changing. Such changes can create uncertainty about causality underlying social and ecological interactions, and the validity of the knowledge collected about these interactions. When a natural environment undergoes dramatic change, such as a major species distribution shift, it impacts the relevance and sometimes the reliability of previously collected information. This can pose severe challenges for those trying to understand and manage social-ecological interaction (Polasky et al. 2011). Knowledge limitations and uncertainty often leave room for multiple interpretations and hypotheses on the quantity and quality of natural resources under observation. The uncertainty that is created in this way can create situations where knowledge is obfuscated or even repressed due to strategic motives (Folke et al. 2007).

\section{Methodology: process tracing}

As indicated above, the method of process tracing is especially suited when it is impossible to control for intervening variables, i.e., when causality is complex. For the study of the historical development of the mackerel dispute, we used "explaining outcome process tracing," which is a type of process tracing where the primary ambition is to explain particular historical outcomes (Beach and Pedersen 2013).

To execute this method, we carried out semi-structured interviews with experts from the Coastal States (i.e., Norway, Faroe Islands, Iceland, and the EU) and the International Council for the Exploration of the Sea (ICES). The pool of 26 interviewed experts consisted of politicians, civil servants, scientists, and industry stakeholders. The interviews included open-ended questions inquiring about the historical development from the shift in stock distribution of northeast Atlantic mackerel in 2007 to the political deadlock in 2014. The interview questions were adapted to each respondent according to their field of expertise, but aimed at understanding the social, political, and ecological factors that triggered and sustained the social conflict.

In the following description of the mackerel dispute, we provide anonymized quotes from the interviews to highlight not only the perceptions of the actors involved but also as evidence for our claims. Unfortunately, some respondents preferred to have their quotes not appear in this paper as they felt that their inclusion could harm the integrity of the political negotiations. Of course, we respected that request. The wish of some respondents to exclude their quotes shows that the mackerel dispute continues to be a highly sensitive social and political process. 
The interview study was complemented with a literature review of the scientific and public media coverage of the mackerel dispute. The data was used to construct a causal chain backward in time (Walters and Vayda 2009), so from the dispute to the mackerel shift. The description of the historical development was then analyzed to identify causal mechanisms that could explain why and how environmental change can lead to conflict.

It should be emphasized here that although we deductively selected social factors to focus our investigation, we used induction to identify how these factors "worked," i.e., how they mediated the causal pathway between environmental change and conflict. In other words, we used the interviews to understand how institutions, power, and knowledge operated and interacted in this particular case.

\section{Case study: the shift of the northeast mackerel}

The northeast Atlantic mackerel (Scomber scombrus, Linnaeus 1758) is a migratory species that covers considerable distance between the areas where it spawns, feeds, and overwinters (Lockwood 1988). Three different stock components can be identified based on their separate spawning locations, referred to as the North Sea, Western, and Southern components. The three stocks are nevertheless managed as one stock, because in late spring and summer, after spawning, the stock intermingles on their way northwards to their feeding areas. These feeding grounds used to lie in the southern Norwegian Sea and the northern North Sea, after which the stocks return to their over-wintering areas at the edges of the continental shelf (ICES Factsheet 2016).

Changes in the geographical distribution of the northeast Atlantic mackerel stock have induced an international conflict between the EU, Norway, the Faroe Islands, and Iceland. As so-called Coastal States, these countries are responsible for management of the stock. Fish stocks that reside in the international waters of the northeast Atlantic, like the mackerel, are multi-laterally managed by the North-East Atlantic Fisheries Commission (NEAFC), where the contracting parties - the EU, Norway, Iceland, Russia, and Denmark (on behalf of the Faroe Islands and Greenland) - negotiate the division of fishing resources. When stocks frequent the national waters of a nation, defined as a 200-mile exclusive economic zone (EEZ), that nation is considered a "Coastal State" for that stock and has the right to harvest it in their EEZ.

The management of the straddling stocks in the northeast Atlantic is a two-tier process: Coastal States agree on shares and management plans before bringing the matter to NEAFC to cover fisheries in waters outside national jurisdiction (Vanderzwaag and Russell 2010). The regulatory area of NEAFC consists of the North-East Atlantic Ocean, the Barents and Norwegian Seas, and the Arctic Ocean (Fig. 1).
The inter-state conflict, the so-called mackerel dispute, started when in 2007 the stock migrated and spawned further towards northern and western regions of the Nordic Seas and their surrounding coastal and oceanic waters (Fig. 2) (ICES Advisory Committee 2013; Nøttestad et al. 2014a). The area of migration has progressively expanded as far as Icelandic and south Greenlandic waters in the west, and as far north as Spitzbergen.

The observed distributional changes may reflect changes in food availability and may be linked to increased water temperature, and/or increased stock size; yet the precise reasons for the shift remain unclear. Although there is reasonable indication that higher sea temperatures are contributing to changes in abundance and distribution, caution must be taken when labeling this conflict as a climate conflict due to the existing uncertainties pertaining to the drivers of the shift (Sherman et al. 2013). Furthermore, a question also remains as to whether these changes in distribution are permanent or temporary (ICES Advisory Committee 2014a). As we will discuss, the knowledge about what causes the mackerel shift is contested, because it influences the legitimacy with which Coastal States claim shares of the TAC (see also Gänsbauer et al. 2016).

The change in geographical distribution resulted in a "spatial mismatch" (Galaz et al. 2008) because Iceland and its fisheries were not included in the relevant Coastal State management plans. The mismatch - the failure to cover the relevant geographical area and include all the relevant stakeholders - not only resulted in the overfishing of the northeast Atlantic mackerel stocks since 2007 but also eroded the legitimacy and functioning of the existing management plans (ICES Advisory Committee 2014a; World Ocean Review 2016).

A few years after the shift in mackerel distribution, the Coastal States attempted to include Iceland into their negotiations. Eventually, Iceland was granted "observer status" in 2008 and Coastal State status in 2010. Nonetheless, until the time of writing, Iceland has not been involved in the Coastal States' agreements on the total allowable catch (TAC) and quota allocations per country. The main reason for this failure is that a social and political dispute between the Coastal States developed which persists to this day. The conflict prevents collaboration in a joint management plan and subsequently sustainable management of the stock.

\section{Results}

In this section, we describe how factors that are frequently used to explain social action - institutions, power, and knowledge - mediated the effect of changes in mackerel distribution on the social relations between the aforementioned nation 
Fig. 1 International NEAFC waters in orange and Coastal State waters in blue. Source: NEAFC website (Color figure online)

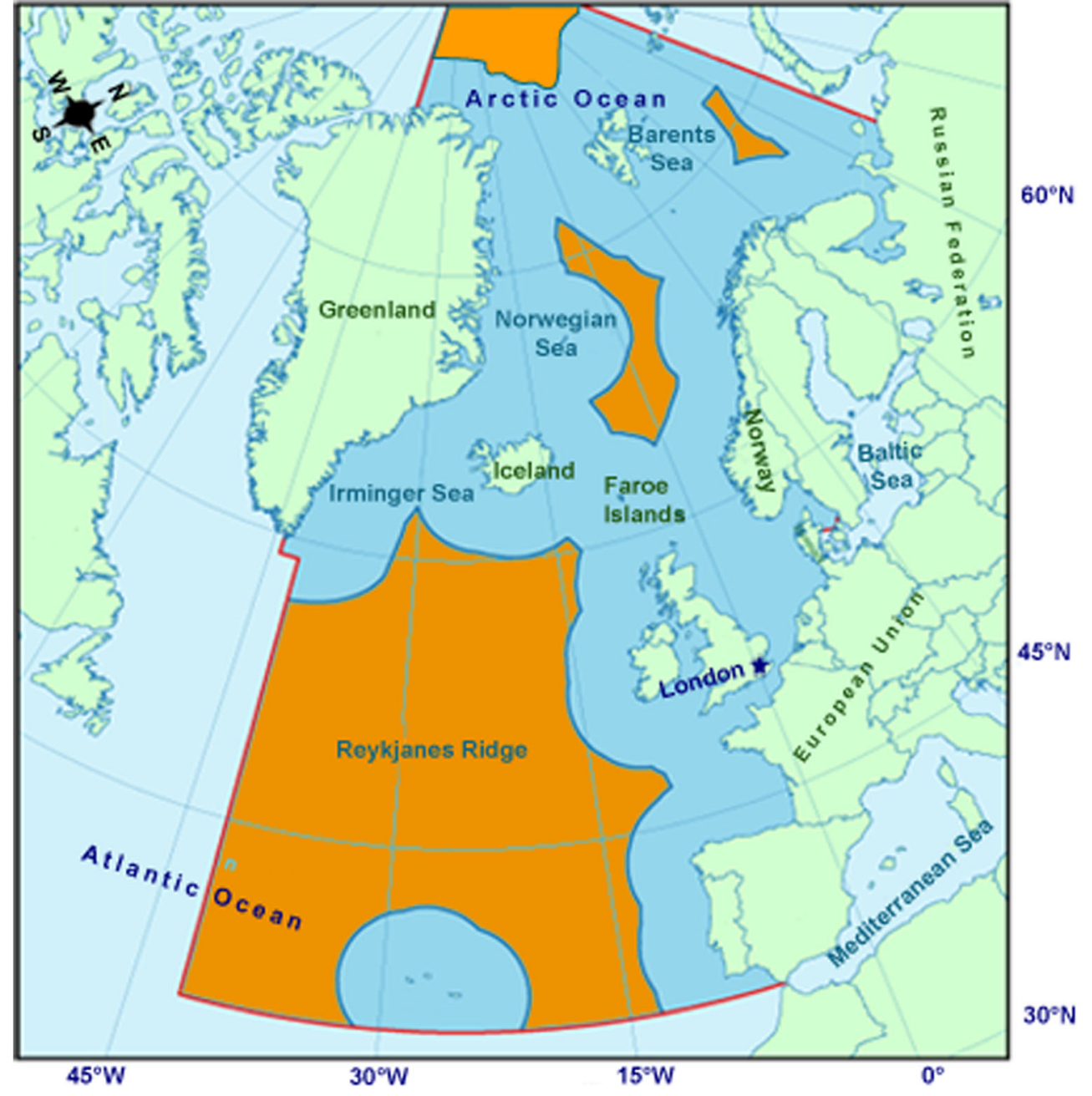

states. We first outline crucial events during the historical development of the mackerel conflict (Fig. 3).

Management of mackerel fishing through NEAFC began in 1999, when the EU, Norway, and Faroe Islands were designated as Coastal States for the stock. Before that time, the EU and Norway had a history of bilateral sharing agreements with other parties (Hoydal 2014). As mentioned, from 2007 the mackerel extended its summer feeding distribution towards the north and west, moving into the EEZ of Iceland.
In 2007, Iceland caught 36,706 tons of mackerel (6\% of a total fish catch of 586,206 tons), and in 2008, increased its catch to 112,286 tons ( $18 \%$ of a total fish catch of 623,165 tons) (ICES Advisory Committee 2014c). The increase in fishing pressure from all Coastal States meant that since 2007, the tonnage of mackerel caught increasingly deviated from the advised catch given by ICES (Fig. 4). As Icelandic catches of mackerel had become considerable, the Coastal States awarded Iceland Coastal State status in March 2010 (OECD 2011).
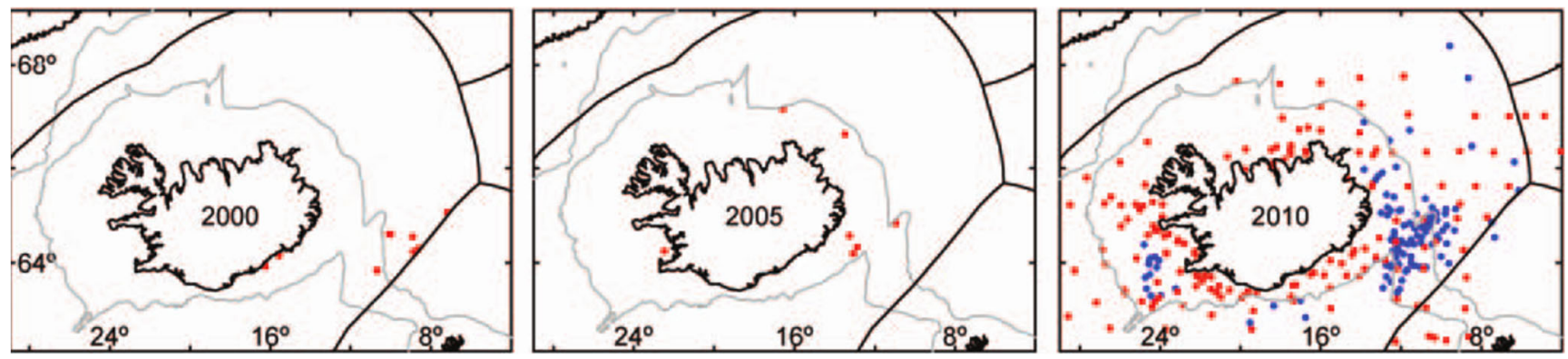

Fig. 2 Locations of mackerel catches from scientific surveys by the Marine Research Institute (red) and of mackerel samples taken by the Icelandic pelagic fishing fleet (blue) for 2000, 2005, and 2010 (Astthorsson et al. 2012: 6) (Color figure online) 


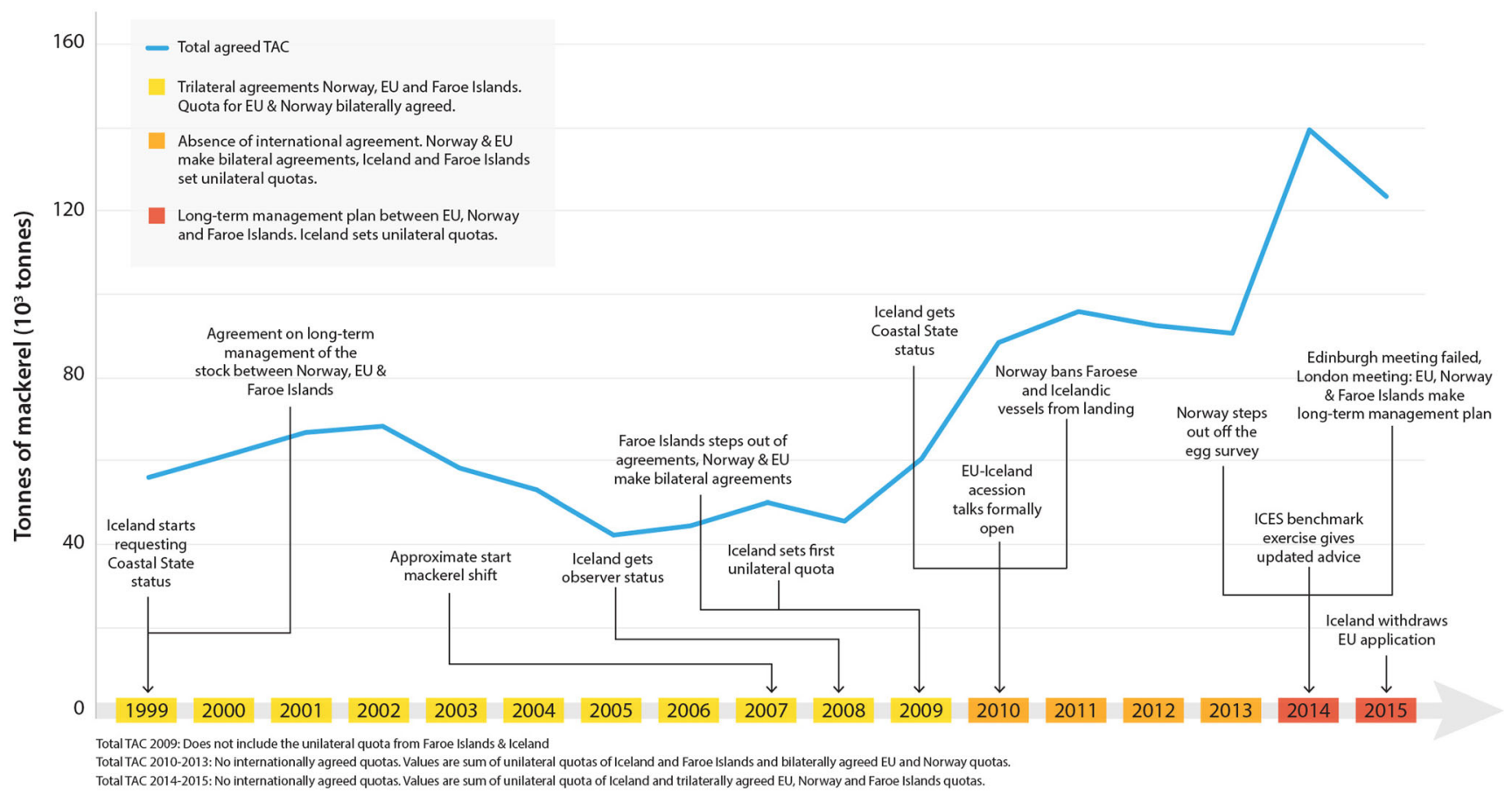

Fig. 3 Timeline displaying important events within the mackerel dispute and the agreed TAC for all Coastal States. Data for that total agreed TAC taken from ICES (2015)

When Iceland became a Coastal State, it had the responsibility together with the other Coastal States to agree on the sustainable management of the stock, which includes the allocation of quotas. Yet, in this new constellation, the Coastal States were unsuccessful in reaching an agreement on quota allocation. Instead, the States got entrenched in a political stand-off due to differing views about appropriate entitlements for each State (both in terms of volumes of allowed catch as well as potential access to other States' waters for catching those volumes). In the meantime, Iceland and the Faroe Islands have set unilateral quotas (Seafish 2014). The Faroe Islands withdrew from the Coastal States' agreements it had made with Norway and the EU in 2009 and allocated a TAC for mackerel unilaterally. The EU reacted to this break away by sanctioning the Faroe Island through trade restrictions in August 2013 (Jensen et al. 2015). The sanctions resulted in an embargo of imports of mackerel (products) to the EU. Moreover, the EU also restricted the access of Faroese fishing vessels to EU ports (European Commission 2013). The conflict between the EU/Norway and the Faroe Island eventually dissolved in March 2014 with a new management agreement, which allocated a substantially larger mackerel quota to the Faroe Islands (Government of the Faroe Islands 2014; Droesbeke 2015).

The negotiations between the Coastal States are informed by scientific information about the status of the mackerel stock. Scientists conduct egg and trawl surveys to estimate the abundance of the stock. More precisely, Norway conducts trawl surveys since 2009 together with Iceland and the Faroe Islands, and egg surveys were conducted by Norway and the
EU. This situation changed in 2014 when Norway stepped out of the egg survey and only endorsed the trawl survey. Beginning in 2009, fisheries scientists raised doubts about the accuracy of the data coming out of the egg surveys (ICES Advisory Committee 2014b). The scientific information structurally underestimated the abundance of the stock, which resulted in too conservative advice on quota shares (ICES Advisory Committee 2014a). To refine data and update advice, ICES performed a benchmarking exercise in 2014. Nonetheless, the size of the mackerel stock remained a point of contention among the Coastal States ever since 2009. The Coastal States differ in their opinion about how much the stock size was underestimated, where Norway holds the position that the actual stock size could be much larger.

Despite these differences in interpretation, an agreement on the allocation of TAC's for all Coastal States seemed finally in reach during the Coastal State meeting of March 2014 in Edinburgh, but again failed to materialize. In the end, Iceland was not included as partner in the agreement, while the other Coastal States agreed upon quota allocations and long-term management of the stock (2014-2018) (Droesbeke 2015). Below follows the analysis of why this dispute over mackerel originated and endured.

\section{Institutions}

It is increasingly recognized by marine scholars and fisheries managers that institutional failures are an important contributor to deteriorating ocean health (Ekstrom and Young 2009; 


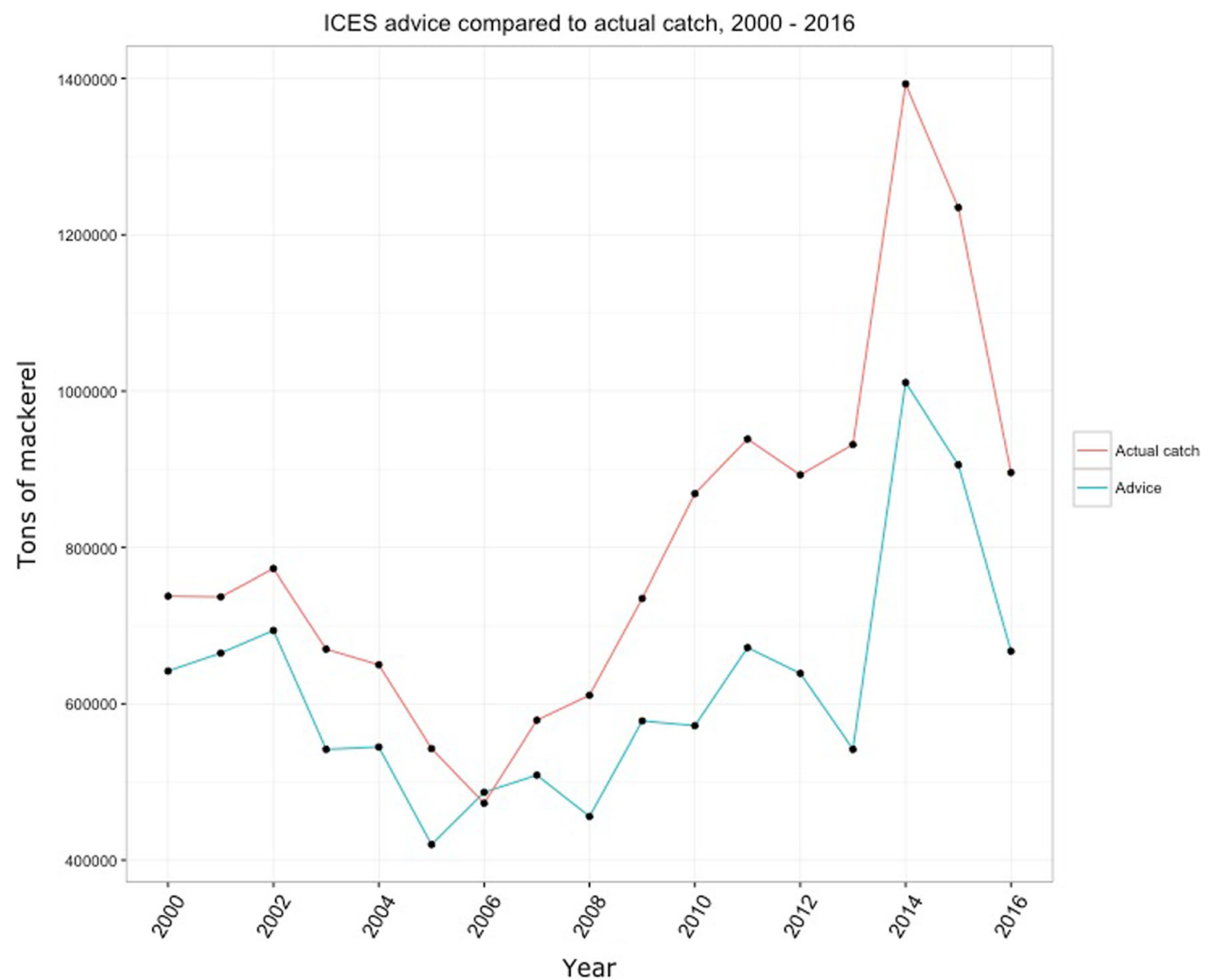

Fig. 4 Upper limit of ICES advice (i.e., highest tonnage recommended) compared to actual catch (2000-2016) (ICES 2015). Remarks on certain data points: year 2014 "advice" data point updated advice after benchmark exercise by ICES, year 2015 "actual catch" data point total

Boonstra et al. 2015; Pauly and Zeller 2016). One way to observe this type of failure is to consider the differences between scientific recommendations and the amount of fish actually caught. Figure 4 demonstrates that despite ICES catch recommendations and management efforts, Coastal States overfished the mackerel stock increasingly from 2007 onwards.

The legal framework that stipulates obligations for Coastal States is the United Nations Convention on the Law of the Sea (UNCLOS) of 1982 and the UN Fish Stocks Agreement (UNFSA) of 1995 (Cox 2009). The framework imposes cooperation to ensure proper conservation management and prevention of over-exploitation of living marine resources, and provides some guidance as to how Coastal States should allocate fishing quotas (Article 7 and Article 11 of the UNFSA) (Cox 2009). Principles put forward by this framework include historical catches, zonal attachment, economic dependency, participation in research, and accessibility. Yet, how the Coastal States choose to apply those principles is not formalized (Nordic Council of Ministers 2011; Ørebech 2013). agreed TAC (i.e., not actual catch as recorded by ICES), year 2016 "actual catch" data point TAC as stated in the Coastal States agreement for 2016 (not taking into account unilateral quotas)

The legal framework has often proved inadequate in aiding the Coastal States to come to a sharing arrangement satisfactory to all. Numerous breakdowns in sharing arrangements have occurred with regard to the three pelagic straddling stocks of the North-East Atlantic, i.e., the Norwegian springspawning herring, blue whiting, and mackerel (Nordic Council of Ministers 2011). Social conflict and ensuing breakdowns are most likely to occur when fish species change migration patterns and distribution areas (Nordic Council of Ministers 2011), as exemplified with the mackerel case. Based on the information from our interviews with principal stock negotiators, there appear to be two major issues with respect to the legal framework that prevent an inclusive mackerel agreement.

Firstly, there is no international agreement among the Coastal States on how the principles laid out by the UNFSA should be weighed against one another (Nordic Council of Ministers 2011). In practice, the final allocation is the result of a process of political bargaining in which Coastal States argue opportunistically for allocation 
principles. Which principles should be considered and how those should be weighed differ among the Coastal States. In this case, Norway is of the opinion that mackerel allocations should mainly be based on zonal attachment (i.e., share in the overall quota should be equal to the share of the stock in a State's EEZ). The Norwegians considered other allocation principles legitimate, but only up to a certain extent. The other Coastal States, however, wanted to allow for more weight of other principles (e.g., more weight on the "dependency on the fishery" criteria). This point is illustrated by the following quote by an Icelandic civil servant:

Norway is very much occupied with the thought of zonal attachment. And understandably [so]. Zonal attachment is important, I agree. But the problem is how much it should weigh in the overall equation. There are other factors $[\ldots]$ But how much each of those factors are weighing is not defined. So that's one of the problems of course!

Many interviewees highlighted how legal indeterminacy leads to political bargaining over the value and validity of scientific knowledge, and consequently, to conflicts over which allocation principles should be applied. The legislative principles for allocation of quota that guide the negotiations are open to multiple interpretations as the principles do not determine the legal outcome of the negotiations. Because of this legal indeterminacy, the Coastal States frequently shift their perception on how these principles should be weighted according to their own interests in the stock under consideration. A Coastal State might for example defend the 'zonal attachment' principle as major sharing criteria for the mackerel stock, yet adhere to another principle during herring or blue whiting negotiations.

Secondly, there is no international agreement on how to translate certain sharing criteria put forward by UNFSA into functional calculations for quota allocation. Controversy particularly surrounds the calculation of zonal attachment. Norway, for example, adheres to the calculation of zonal attachment as developed by marine scientist Johannes Hamre, but this so-called Hamre-model was not considered a relevant nor applicable method for calculating zonal attachment by some other Coastal States. There is also no established formula for the calculation of other sharing criteria such as dependency on the fishery and "historical catches." It almost goes without saying that this ambivalence triggers perpetual debates-how far back should one look to determine historical catches of a Coastal State; should one base dependency on a per capita figure, or on the dependency of the fishing industry?
Due to the legal indeterminacy described here, agreed allocations are the result of incessant bargaining, a process where "all that matters is strategy, legislative strength, bargaining power and "cleverness"” (Ørebech 2013: 362). The ambivalent legal framework is prone to lead to social conflict and even opt-outs from displeased Coastal States, or the exclusion of Coastal States from an agreement by others with greater power. Despite the recognition of the failures of the legal framework amongst the Coastal States' negotiators, the institution persists because certain participants benefit from its current form and function (Ekstrom and Young 2009).

\section{Knowledge}

The relation between the production of scientific knowledge and socio-political conflicts comes out clearly in the mackerel case. The abruptness and magnitude of the shift in stock abundance and shifting location caused a great deal of scientific uncertainty pertaining to several ecosystem dynamics with respect to (a) the specific drivers and longevity of the shift, (b) the abundance of the stock, and (c) the effect of the changed distribution pattern and higher abundance of the mackerel on other (marine) species (Óskarsson et al. 2012; ICES Advisory Committee 2014b). These uncertainties in combination to opposed interests of the Coastal States polarized views on the ecological and biological dynamics of the mackerel stock that were observed.

Firstly, there was uncertainty regarding the longevity of the mackerel migration. Has the stock shifted permanently or is the shift transient? Despite this uncertainty, several interviewees hold the opinion that Norway bases its management policies on the assumption that the stock might shift back to its original habitat. According to a representative of the Icelandic fishing industry, the framing of the mackerel shift as temporary is used to deny the Icelandic claims:

They [the Norwegians] have been quite open about their view that [the mackerel shift] is only a temporary thing. I guess that's one of the things that's driving their policy, that they're not going to give in and give us a piece of something that we won't have a piece of in the future.

Secondly, beginning in 2009, scientists increasingly realized that they underestimated the abundance of the stock, yet to which extent is contended. Part of this uncertainty stems from the diverging outcomes of surveys that estimated the abundance of the stock, i.e., the egg survey and the trawl survey. The trawl surveys, performed by Norway, and since 2009 by Iceland and the Faroe Islands, suggested a larger Spawning Stock Biomass (SSB) than the egg surveys. This difference is indicated in Table 1 . The egg surveys were performed by Norway and the EU, but from 2014 onwards, are performed only by the EU as Norway stepped out. 
Table 1 Difference in SSB estimation between the egg and trawl survey. Magnitude of numbers $=$ million tonnes $($ table compiled using Nøttestad et al. 2014a, 2014b; ICES Advisory Committee 2014b)

\begin{tabular}{llllllll}
\hline & 2004 & 2007 & 2010 & 2011 & 2012 & 2013 & 2014 \\
\hline $\begin{array}{l}\text { SSB estimates based on trawl survey } \\
\text { SSB estimates based on egg survey } \\
\text { (before benchmark }^{c} \text { ) }\end{array}$ & Missing & 1.25 & 4.52 & 2.45 & 4.56 & 7.87 & $\begin{array}{l}8.98 \\
\text { d }\end{array}$ \\
\hline
\end{tabular}

a "Swept area biomass was not estimated for the years 2008 and 2009 due to poor horizontal coverage in 2008, sub-optimal pelagic trawling aimed at Atlantic salmon in 2008 and 2009, and too varying and poorly coordinated survey for the different vessels in 2009" (Nøttestad et al. 2014a: 7)

${ }^{\mathrm{b}}$ Combined western and southern components

${ }^{\mathrm{c}}$ A benchmark assessment was held in 2014 to update the stock assessment model used for mackerel, as the validity of its assumptions has been questioned. SSB estimations for the egg survey were recalculated after the benchmark process

${ }^{\mathrm{d}}$ Egg surveys are only done triennially (North Sea component 1 year later)
Because the trawl surveys structurally indicated a larger SSB (see year 2013 in Table 1), ICES performed a so-called benchmark exercise in February 2014 to update their advice on catch limits (see Fig. 3). For this exercise, they integrated the trawl survey as a parameter into the stock assessment model that was previously used as a base for giving advice on the stock. After the update, the Coastal States agreed that the stock size had been underestimated. Yet the extent of the underestimation remained a matter of contention due to the different outcomes from the egg and trawl survey. The validity and rigor of the respective surveys was heavily disputed. Coastal States preferring the outcomes of the egg survey (mainly the EU) argued that the trawl survey had flaws, while for example some Norwegian representatives highlighted problems with the egg survey as illustrated in this quote:

And the development according to the eggs survey is that it's showing a slight increase [in spawning stock biomass] but now the last year it's been showing a decrease and this is not fitting at all with what we see in the trawl survey $[\ldots]$ with our common sense and with our scientific approach the egg survey is not logical from our point of view.

Some interviewees suspected that the trawl surveys were used in a strategic manner to legitimize claims for larger catch quotas, as those surveys indicated a larger SSB (a larger stock biomass could legitimize a larger overall catch quota).

Thirdly, from 2011 onwards stock assessments suggested that the high abundance of the mackerel and its distribution into new waters could have effects on other (marine) species within some of the Coastal States' ecosystems. In 2012, Icelandic scientists reported that the mackerel gains around $43 \%$ of their body weight in Icelandic waters which can be expected to have measurable impacts on the ecosystem since the mackerel might outcompete other species for food (Óskarsson et al. 2012). The EU and Norway, however, denied the relevance of this knowledge for negotiation of the sharing arrangements. A Norwegian civil servant expressed this viewpoint as follows:

Iceland made their own version about [mackerel] weight gain and zonal attachment. It's an interesting approach, but so far it's only Iceland who's doing it, calculating zonal attachment this way [...] It doesn't change the relative [quota] sharing between Norway and Iceland at all, since the mackerel also feeds extensively in Norwegian waters.

Around the same time, research was published that put forward the possibility of the Atlanto-Scandian herring being outcompeted for food by the mackerel within Norwegian waters (Langøy et al. 2012). For Norway, this was extremely important knowledge because they hold approximately $60 \%$ of the Norwegian Spring-Spawning herring quota. Several respondents believed that this knowledge incentivized Norway to safeguard their claims on mackerel quota. This argument is illustrated with a quote from an EU stock negotiator:

You can be pretty sure that [the herring] is going to continue to decline for the next three years or so. There's not much happening there so it's in trouble. Of course that means that, Norway is the biggest stakeholder in the Atlanto-Scandian herring, that all their pelagic processing plants need fish. So there's a big pressure on them to have more blue whiting and more mackerel.

In sum, the abrupt and extensive change in mackerel migration created scientific uncertainties which in turn had decision-makers accusing each other of delegitimizing, misusing, or ignoring ecological information (Polasky et al. 2011). Especially, the uncertainty pertaining to the abundance of the stock and the validity of the surveys used to estimate abundance emerged as a matter of dispute. The controversies around the appropriate level of fishing pressure then blocked a deal amongst all Coastal States. The case highlights how lack 
of scientific certainty can create opportunities for strategic presentation, use, and interpretation of facts, and consequently, the origin and duration of conflicts (Polasky et al. 2011).

\section{Power}

Power is considered essential for explaining causality in social-ecological interactions, and, through such explanations, to allocate responsibility for social and ecological outcomes (Boonstra 2016). Investigation of the role of power in the case of the mackerel mismatch helps to understand the interdependence between the major players in this case, and why until now they fail to implement a functional agreement and management scheme.

Historically, there has been a strong alliance between the EU and Norway in fishery negotiations (Ørebech 2013). These two parties agreed on bilateral arrangements for the mackerel stock well before 1999 and have several other shared agreements with relation to the stocks in the North Sea. Together, the EU and Norway stalled Iceland's request for inclusion as Coastal State for 11 years, from 1999 until 2010 (Ørebech 2013). After Iceland was accepted as Coastal State, Norway and the EU initially saw no legitimate reason for giving Iceland (and the Faroe Islands) a (larger) quota share.

A few years after the shift in mackerel distribution, both Iceland and later the Faroe Islands requested a (larger) share of quota. The main reason behind these demands is the increased abundance of mackerel in the EEZ of these countries. Moreover, the national economy of the two countries also substantially depends on the income from fisheries (Gänsbauer et al. 2016). Yet, the EU and Norway initially denied their claims. At that stage, both the EU and Norway preferred to maintain the status quo and opposed opening up the sharing arrangements.

Their opposition was based on the UNFSA principles of "historical fishing rights" and zonal attachment (Ørebech 2013). The first principle argues for Iceland's exclusion from the quota sharing because it had not participated in the mackerel fishery in the past. The second principle is based on the biological distribution of the stock throughout the year: the quota is then decided on the basis of how much of the stock resides within each country's EEZ. Though there is no internationally agreed method to calculate the zonal attachment principle, the Norwegian delegation holds the opinion that the principle denies Iceland a significant share as the mackerel does not reside for an extensive period of time within the Icelandic EEZ.

Besides those two formal arguments based on the UNFSA principles, many interviewees maintained that Norway had an ulterior reason to withhold giving a share to Iceland: Norway's suspicion that the distribution shift was of a temporary nature (Ørebech 2013). The arguments presented by the EU and
Norway are expressed in the following quotes by two Icelandic delegates:

[Norway and the EU] are simply saying that [Iceland] is [a] newcomer to this; that the fact of the matter is that the mackerel is [in the Icelandic EEZ] for a very short period; and that our 16 or 17 percent claim just doesn't add up if you look at the criteria of [...] zonal attachment [and] historical catches.

But I remember Norway talking about this, [that] this might be temporary. 'We don't know if there's going to be mackerel next year in Iceland', so they brought up that point, more than EU.

The claims of Iceland and the Faroe Islands were thus deemed illegitimate and were not incorporated into the Coastal States' agreements, resulting in the two countries setting their own unilateral quotas. The Faroe Islands did so from 2009 until March 2014 (Droesbeke 2015), because they felt that the agreements did not reflect the changed geographical distribution of the stock. Mackerel had become more abundant in Faroese waters, so they argued that they were deserving of a larger share of the TAC. However, the EU and Norway initially did not acknowledge those claims (Jensen et al. 2015). As the following quote from a Faroese civil servant makes clear, the Faroe Islands discontent with the dominance of the EU and Norway in the negotiations had been simmering for some time:

There had long been a dissatisfaction with the way in which that three party arrangement [EU; Norway; Faroe Islands] worked in practice. Basically it started as a bilateral thing between Norway and the EU and the sense was that we were kind of there as an irritation on the side, a 'throw them some crumbs and keep them happy' kind of thing.

Iceland too was setting their own, unilateral quotas since 2009. The unilateral Icelandic quotas evoked anger especially within the European fishing industry. Both the EU and Norway responded to the quotas by the use of trade mechanisms to push Iceland towards decreasing their catch shares. Norway, for example, banned Icelandic and Faroese vessels from landing in Norway in 2010 (Norwegian Ministry of Fisheries and Coastal Affairs 2010) and the EU developed and adopted a regulation whereby the European Commission may take restrictive measures against a country allowing "non-sustainable fishing" (Council of the European Union and European Parliament 2012).

The power struggle in this conflict has been one where the EU and Norway initially united to maintain the status quo concerning the sharing of the TAC for mackerel, while 
Iceland and the Faroe Islands made efforts to secure a (larger) share of the catch. The Faroe Islands did so by breaking up earlier agreements, while Iceland adhered to an alternative weighting of existing allocation principles (more focus on the economic dependency criterium) or introduced new elements they thought should be considered while deciding on quota allocations (e.g. the impact of the high influx of mackerel on their national ecosystem). When their argumentation proved unsuccessful, they instead set unilateral quotas.

This situation began to change around 2012 (Ørebech 2013). During this time, the EU became more favorable of including Iceland in the Coastal State agreements, which consequently meant giving them a substantial share. In October 2013 Iceland and the EU reached an informal agreement, brokered between the Icelandic fisheries minister and an EU Commissioner. The change in position of the EU had to do with the fact that the science indicating a strong presence of mackerel in the Icelandic EEZ became more and more accepted within ICES, yet the change was also tied to political motives. On 27 July 2010, the EU and Iceland had begun talks about Iceland's accession to the EU as a Member State. During these talks, fisheries appeared as a major issue and a potential obstacle preventing Iceland's accession. The EU therefore had an interest in resolving the mackerel dispute as leverage for the accession talks with Iceland. As stated by a high-level representative of DG MARE:

For [the EU Commissioner] back then this was a highly political thing and it was most politically useful to have the mackerel issue resolved before the start of negotiations [on accession]. So, that was the idea. To open the negations on the fisheries chapter once the mackerel [issue was resolved].

It was in the Coastal State meeting of March 2014 in Edinburgh that an agreement including all Coastal States seemed finally in reach. The EU and Iceland had agreed to an informal deal struck a few months earlier that Iceland would get $11.9 \%$ of the mackerel stock. Despite the fact that Norway was not informed of this percentage that arrangement seemed (at least to the Icelanders) like a "done deal." However, this deal would never materialize. In fact, Iceland remained outside any Coastal State agreements because Norway objected to this deal being brokered without their involvement:

In Edinburgh [...] it's fair to say we were really close to reaching an agreement. Before Iceland and EU had bilaterally reached an understanding [...] the famous $11.9 \%[\ldots]$ then things played out very differently, not only very differently, the Norwegians came very upset how then Iceland and not least the EU approached the issue and how they played it. Eventually I think the
Norwegian position almost became so that they said "11.9, never! Maybe 12!". My point is, 11.9, it is never going to happen. Because of the exact way the figure came about (Icelandic civil servant).

The near outrage Norway felt when learning about the deal made between Iceland and the EU, is illustrated by the following quote:

The EU commission chose to stab Norway in the back. It's as simple as that [...]. But the way how [the EU] did it, probably annoyed people at every level; from the industry representatives, civil service and politicians [...] The strategy was discussed at high political levels (Norwegian civil servant).

Even though Iceland was not part of any agreement, the other Coastal States did make an agreement in March on the long-term management of the stock (2015-2018) (Fig. 3). The agreement has a strong Norwegian imprint. Firstly, Norway secured their wish for a higher agreed TAC (Fig. 3). The EU consented simply has an agreement in place as the following quote makes clear:

We didn't like it, we wanted to stay within scientific advice. But we thought that it would be the price to pay to get an agreement to keep things down for the next year. So, in the mackerel agreement it is written that from 2015 we stick with scientific advice (EU civil servant).

Secondly, the Faroe Islands saw their share increase substantially (the Faroese share in 2009 was less than $5 \%$ of the total agreed TAC, while in 2014 it became more than $11 \%$ (ICES 2015; European Union, Norway, Faroe Islands 2015)). This was a change that Norway was advocating:

[The Faroese stock negotiator] knew that it was possible for him to get an agreement with Norway because even though we didn't say it directly out [...] Norway came to believe during the negotiations that the Faroese had too little mackerel (Norwegian civil servant).

Thirdly, Norway kept Iceland from fishing in any other waters but their own by requesting the Faroe Islands that they would not let Iceland fish mackerel in their waters. This was met with indignation from the Icelandic side, which is illustrated by this quote from a Norwegian civil servant:

But they [the Icelanders] were very angry with Norway when we secured that they couldn't fish mackerel in Faroese waters either [...] We have an agreement with Faroe Islands for the entire [period of the agreement] 
that Iceland cannot fish in their waters [...] So we tried to fence Iceland in every way... it was damage control from our part.

These results demonstrate that during the last Coastal State meetings, the balance of power tipped towards Norway, as they secured their wishes of both a larger TAC and limited Iceland's access to mackerel beyond their EEZ. The intention of the EU to allow Iceland a larger share completely backfired. Norway was able to push for those changes because they used bargaining tactics that involved potentially dissolving other agreements made with the EU concerning different marine species.

\section{Discussion}

As explained previously, the relation between environmental change and social conflict is not straightforward, but rather represents a nexus where various causal factors interlink. The mechanisms that produce and reproduce the mackerel dispute - institutions, power, and knowledge - causally interrelate. By considering the historical development of this dispute, we can discover inductively how these factors reinforce and react together (Mahoney 2001), creating a causal pathway between environmental change and social conflict. To emphasize the point: it does not suffice to establish the presence of causal factors; it is necessary to also consider how they interlink through time to understand how environmental change can initiate enduring social conflicts (Homer-Dixon 1999). In what follows, we present two causal interplays that shaped the mackerel dispute.

\section{Power shapes knowledge}

What we hold for true depends on whose knowledge we trust (Carolan and Bell 2003), which means that knowledge is produced and reproduced through how people are interconnected. Analyzing social relations through the concept of power highlights how balances of power, i.e., the various relational interdependencies between people, shape what knowledge is accepted as valid and valuable (Foucault 1980; Flyvbjerg 1998). Understanding established knowledge as a "discursive product of power" also directs attention to knowledge that is disqualified as "inadequate, naive, and lacking scientificy" (Carolan and Bell 2003: 228). The mechanism of power/knowledge (Foucault 2000 [1982]) comes out in the mackerel case when one considers the way in which the Coastal States dealt with scientific ambiguity in relation to the condition of the mackerel stock, and the way in which the individual states endorsed certain scientific methodologies.
Before the mackerel shift in 2007 the "main players" (Ørebech 2013: 362) in the Coastal State meetings were the EU and Norway. These countries had been dealing with the sharing of the stock since 1999, had the biggest mackerel fishing fleet, and worked together on the scientific surveys that are used to advise the States on quota allocations. The Faroe Islands only played a minor role in the quota negotiations, and Iceland was not considered as a Coastal State. This situation began to change after the mackerel moved northwards. Due to this change in distribution, Icelandic and Faroe fishers got better access to the stock and therefore wanted to secure their fishing rights. The Faroe Islands wanted to enlarge their mackerel quota, while Iceland wanted to change its observer status to become an accepted Coastal State member to secure their quota share. Initially, the EU and Norway dismissed both these claims, as is illustrated by the following quote of an Icelandic stock negotiator:

Then for instance when we came to the table as observers in 2008, the others [the EU and Norway] claimed that Iceland was not a Coastal State; -there is no mackerel in Icelandic waters-, they said. We replied "there must be mackerel there, we have been catching mackerel"; "well it's probably more herring that you claim is mackerel.

The Icelandic statistics showing increased catches of mackerel were not acknowledged as valid during the first years after the distribution shift. The EU and Norway initially questioned the validity of their data (e.g., if it was really mackerel they were catching and reporting), and the scientific logic underpinning their arguments. Acknowledging the validity of this data would potentially reduce the quotas that the EU and Norway enjoyed. Nevertheless, in 2009 Iceland was accepted in the negotiations because their catches had simply become "too big to ignore." This demonstrates how powerful actors are able to bar potential participants from the Coastal State agreement by questioning scientific knowledge, which ultimately helps them avoid a reduction of their own share.

Another manifestation of this mechanism is when the EU and Norway disagreed with the validity of the ecological arguments Iceland used to secure or enlarge their quota share of mackerel. Iceland argued that the mackerel was gaining around $43 \%$ of their body weight in their waters, which impacted their marine ecosystems (Óskarsson et al. 2012). The Icelanders considered that impact as a legitimate reason for a larger share of the mackerel quota:

So we say "this is an unusual invasion and we must take a fair share. It is estimated that this 1.5 million [of mackerel] is increasing in weight by some 600-700.000 tonnes while in our waters. So why shouldn't we take 150.000 tonnes or a similar part of that? 
In the view of the EU and Norway, this argument is not a legitimate reason to alter sharing arrangements. In a recent publication, Gänsbauer et al. (2016) also highlight how the insecurity over the reasons behind the mackerel shift allows countries to select the scientific explanation that best serves their interests. Accepting that the shift is caused by climate change would confirm the permanence of the shift. This explanation is advantageous for Iceland and the Faroe Islands, but not for the EU and Norway because they would have to accept a (semi)permanent decline in their share of the TAC. Consequently, the latter countries prefer to consider the shift as temporary and the result of 'normal' environmental fluctuations.

\section{Institutional failure creates power}

The other causal interplay that can be observed in the mackerel dispute was between legal indeterminacy and power. Because the argument put forward by Iceland (the feed mackerel take-up from Icelandic waters) was not a traditional UNFSA sharing principle, the EU and Norway denied its relevance for sharing arrangements. In that way, we can see how the principles of the existing legal framework are a source of power the historical fishing nations have within the negotiations. The EU and Norway are able to use the "rules of the game," in this case, the sharing principles to their benefit.

In the years right after the shift, Norway and the EU could evoke the historical fishing principle to question the legitimacy of an Icelandic share, as the principle allows them to discriminate against former non-participants when allocating fishing rights (Ørebech 2013). In that way, one of the principles from the legal framework can be used to exercise power and maintain the status-quo, even though that principle does not guarantee sustainable harvesting nor fair sharing (Ørebech 2013). Rather to the contrary, the historical fishing principle is primarily based on the structure of historic fisheries and not on ecological parameters such as geographical distribution.

All Coastal States can adhere rather opportunistically to principles due to the legal indeterminacy of the UNCLOS and UNFSA framework. The framework does propose sharing principles, but does not explicitly state which ones should be used and in what way, or how to establish trade-offs (Ørebech 2013). It only requires that the member states agree on "the establishment of total allowable catches and their allocation to Contracting Parties" (ibid. 2013: 361). As a result, the historic fishing nations not only "control the entry conditions and procedures" (ibid. 2013: 360) for those seeking to become a Coastal State, they can also effectively bar other Coastal States from getting a certain share when it is not based on the criteria they are inclined to favor (Ørebech 2013). The undetermined nature of the legislation and the principles used for allocating the TAC provide Coastal States opportunities to exercise power through bargaining and pressuring.
However, as our case study also demonstrates, the admittance of Iceland as Coastal State changed the balance of power between the various stakeholders (see Miller 2007 for a similar argument in relation to the management of tuna stocks). Because Iceland and the EU were debating the Icelandic accession to the EU while the mackerel dispute was going on, the dispute became linked to the accession talks. Many respondents argued that the accession talks were the reason why the EU began to acknowledge the Icelandic claims in the mackerel dispute. The closer relation between the EU and Iceland consequently weakened the coalition between Norway and the EU. It seems likely that the balance of power between Coastal States will continue to become more equal (Undercurrentnews 2013) with some of the less powerful states claiming larger shares as the shift continues (Iceland and the Faroe Islands), and new countries also demanding access (Greenland recently joined the mackerel fishing).

It is an established sociological insight that the extension of social networks leads to higher interdependence between social groups, which in turn equalizes power balances (Elias 2012 [1939]). With more extensive and complex relations the potential of the individual groups to control processes of interaction decreases (Boonstra and De Boer 2014). The equalization of power also leads dominant social groups to pay more attention to the interests of subordinate groups because the former become more dependent for their own wellbeing on the latter (see also Scott 1985).

\section{Resolving or deepening the conflict?}

Based on our results, we argue that the mackerel dispute is currently experiencing a (re)balancing of power between the various Coastal States due to their growing interdependence. The old Coastal States try to preserve their previous entitlements, while the newcomers propose alternative ways of sharing the shifting mackerel stock. In the meantime, it is likely that the mackerel continues its stay in the north, which increases the mutual interdependence between countries. We speculate that this standoff can develop in two ways.

If countries start to recognize their mutual interdependence, it will become more likely that countries wish to offload responsibility for a fair distribution to a relatively independent institution (Erikson and Parent 2007). Such institutional reform could mean that the current management scheme is likely to become less arbitrary and more independent from the interests of individual countries (Ruttan and Hayami 1984). This is good news both for internal cooperation between stakeholders and the possibility for establishing sustainable fisheries management.

If the Coastal States fail to recognize their growing interdependence, the deadlock could harden and lead countries to intensify their fishing efforts in order to claim a larger share of the TAC. As Homer-Dixon (1999: 107-126) argues the 
combination of intense competition over resources, lack of clear property rights (with open access resources), negative externalities, and scientific uncertainty can severely limit "institutional ingenuity," i.e., the adaptation and innovation of social institutions that can promote fair and sustainable management of natural resources. Not surprisingly, such an outcome spells bad news for both international management of the mackerel and consequently, a sustainable future for this fish. There are some signs that this scenario is currently unfolding (Gänsbauer et al. 2016). With the new agreement, Norway managed to enlarge the TAC, while limiting the access of other Coastal States.

\section{Conclusion}

According to marine and fisheries scholars, the mackerel dispute is an early exemplar of processes of global environmental change that causally relate climate change, fish stock redistributions, adaptations in fisheries, and social conflicts (Cheung et al. 2010). Yet, in many ways, this example differs from the cases that are usually considered to illuminate about the environmental change-social conflict nexus. First of all, it is not a case of violent conflict, an outcome which has been a primary focus of previous work on the environmental change-conflict nexus (Burke et al. 1990; Homer-Dixon 1996; Wilson and Tisdell 2003). The social conflict in the mackerel case is better described as a political stand-off between nation states resulting in an absence of management agreements and consequently, unsustainable fishing. Second, the stakeholders in the mackerel dispute are high-income countries (or regions). This stands in opposition to the economically impoverished regions, which have been the focal point of much conflict research (Elliott 1996, Homer-Dixon 1999, The World Bank 2000). Finally, the mackerel dispute is not a case of environmental scarcity or degradation, which has been the primary focus of conflict research related to the environment (Elliott 1996, Homer-Dixon 1996). In fact, the biomass of the mackerel stock increased until this year, when researchers announced the first possible drop in biomass (Undercurrentnews 2015). Inclusion of this case thus extends the scope conditions in which the environmental change-conflict nexus can manifest itself. The conflict features different types of countries (high-income countries), different sorts of conflict (non-violent conflict), and different types of environmental change (shifting abundance, not necessarily scarcity or degradation).

The advantage of including an unconventional case, such as the mackerel dispute, is that it enlarges the population of potential cases, thereby opening up for a wider consideration of the causal complexity of the environmental change-social conflict nexus. Moreover, the consideration of cases that show other types of environmental change and conflict can help honing more precise propositions about which types of environmental change lead to which types of social conflicts. The disadvantage of considering a wider population of cases is, of course, that it complicates case comparison and therefore generalization.

We navigated this dilemma in this paper by deductively identifying a number of factors that influence social interaction. These included (a) institutions, (b) power, and (c) knowledge. We then investigated if and how these factors worked with a study of the origin and duration of the mackerel dispute. Through inductive reasoning using process tracing, we highlighted how stakeholders used power to influence the development and application of science. Furthermore, with the case study, we also demonstrated how legal indeterminacy created opportunities for stakeholders to exercise power.

We are aware that the significance and validity of the three factors in influencing the pathway from environmental change to conflict will fluctuate from case to case. Indeed, social mechanisms are "sometimes true" (Stinchcombe 1998: 267); they refer to certain, general patterns of causality occurring under specific circumstances. Nonetheless, we foresee that the mechanisms we identified as relevant will hold explanatory value in many other cases where there is a causal link between environmental change and conflict. First, because we selected these mechanisms due to their generic nature and their proven explanatory value within the social sciences. Second, we argue that the mere existence of the three identified contextual factors conjoining with a particular environmental change does not suffice to produce observed (or latent) conflict. Through complex interaction, these factors reinforce each other and create reactive feedbacks that determine the initiation and obduracy of conflicts that will erupt when the effects of climate change will become more visible and profound.

Acknowledgments We would like to thank Henrik Österblom, Tiffany Morrison, and the reviewers and editors of REC for helpful comments and suggestions on an earlier version of this article. We would also like to thank Hlynur Bárðarson, Andrew Merrie, and Jonas Hentati-Sundberg for their guidance and support. Finally, we would like to thank the respondents that devoted their time and information to this study. This paper is a deliverable of the Nordic Centre for Research on Marine Ecosystems and Resources under Climate Change (NorMER) and contributes to the project Green Growth Based on Marine Resources: Ecological and SocioEconomic Constraints (GreenMAR). Mistra supported the research for this paper through a core grant to the Stockholm Resilience Centre. The authors wish to acknowledge that this paper is based on a MSc. thesis written by the corresponding author, Jessica Spijkers, at the Stockholm Resilience Centre, entitled "Exploring misfit: a case study of the northeast Atlantic mackerel" (2015).

Open Access This article is distributed under the terms of the Creative Commons Attribution 4.0 International License (http:// creativecommons.org/licenses/by/4.0/), which permits unrestricted use, distribution, and reproduction in any medium, provided you give appropriate credit to the original author(s) and the source, provide a link to the Creative Commons license, and indicate if changes were made. 


\section{References}

Astthorsson OS, Valdimarsson H, Gudmundsdottir A, Oskarsson GJ (2012) Climate-related variations in the occurrence and distribution of mackerel (Scomber scombrus) in Icelandic waters. ICES J Mar Sci:1-9

Beach D, Pedersen R (2013) Process tracing methods: foundations and guidelines. Michigan

Bergsten A, Galafassi D, Bodin Ö (2014) The problem of fit in socioecological systems: detecting spatial mismatches between ecological connectivity and land management in an urban region. Ecol Soc. doi:10.5751/ES-06931-190406

Boonstra WJ (2016) Conceptualizing power to study social-ecological interactions. Ecol Soc 21(1):21

Boonstra WJ, De Boer FW (2014) The historical dynamics of socialecological traps. Ambio 43:260-274. doi:10.1007/s13280-0130419-1

Boonstra WJ, Ottosen KM, Ferreira ASA, Richter A, Rogers LA, Pedersen MW, Kokkalis A, Bardarson H, Bonanomi S, Butler W, Diekert FK, Fouzai N, Holma M, Holt RE, Kvile K, Malanski E, Macdonald JI, Nieminen E, Romagnoni G, Snickars M, Weigel B, Woods P, Yletyinen J, Whittington JD (2015) What are the major global threats and impacts in marine environments? Investigating the contours of a shared perception among marine scientists from the bottom-up. Mar Policy 60:197-201. doi:10.1016/j.marpol.2015. 06.007

Boyd E, Folke C (eds) (2012) Adapting institutions: governance, complexity and social-ecological resilience. Cambridge University Press, Cambridge

Brundtland GH (1987) Report of the world commission on environment and development: our common future. Oxford Univesity Press, London

Burke M, Hsiang SM, Miguel E (1990) Climate and conflict. RUSI J 135: 79-83. doi:10.1080/03071849008445480

Burke M, Dykema J, Lobell DB, Miguel E, Satyanath S (2015) Incorporating climate uncertainty into estimates of climate change impacts. Rev Econ Stat 97:461-471

Cairns R, Krzywoszynska A (2016) Anatomy of a buzzword: the emergence of "the water-energy-food nexus" in UK natural resource debates. Environ Sci Pol 64:164-170. doi:10.1016/j.envsci.2016. 07.007

Carolan MS, Bell MM (2003) In truth we trust: discourse, phenomenology, and the social relations of knowledge in an environmental dispute. Environ Values 12:225-245

Chaffin BC, Gosnell H, Cosens BA (2014) A decade of adaptive governance scholarship: synthesis and future directions. Ecol Soc 19

Cheung WWL, Lam VWY, Sarmiento JL, Kearney K, Watson R, Zeller D, Pauly D (2010) Large-scale redistribution of maximum fisheries catch potential in the global ocean under climate change. Glob Chang Biol 16:24-35. doi:10.1111/j.1365-2486.2009.01995.x

Council of the European Union, European Parliament (2012) Regulation (EU) no 1026/2012 of the European parliament and of the council of 25 October 2012 on certain measures for the purpose of the conservation of fish stocks in relation to countries allowing non-sustainable fishing. European Union

Cox A (2009) Quota allocation in international fisheries. OECD Food, Agric Fish Pap

Cullen H, Demenocal P, Hemming S, Hemming G, Brown FH, Guilderson T, Sirocko F (2000) Climate change and the collapse of the Akkadian empire: evidence from the deep sea. Geology 28: 379-382

Cumming SG, Cumming DHM, Redman CL (2006) Scale mismatches in Social-Ecological Systems: causes, consequences and solutions. Ecol Soc 11:14
Cumming GS, Olsson P, Chapin FS, Holling CS, (2013) Resilience, experimentation, and scale mismatches in socialecological landscapes. Landsc Ecol 28:1139-1150. doi:10.1007/s10980-012-9725-4

Droesbeke K (2015) The fisheries policy: relationships between Iceland, Norway and the European Union. Universiteit Gent

Ekstrom JA, Young OR (2009) Evaluating functional fit between a set of institutions and an ecosystem. Ecol Soc 14:16

Elias N (2012) [1939] On the process of civilisation: sociogenetic and psychogenetic investigations. The collected works of Norbert Elias. Volume 3. University College Dublin Press, Dublin

Elliott L (1996) Environmental conflict: reviewing the arguments. J Environ Dev 5:149-167. doi:10.1177/107049659600500203

Erikson E, Parent JM (2007) Central authority and order. Sociological Theory 25:245-267

Ernstson H, Barthel S, Andersson E, Borgström ST (2010) Scale-crossing brokers and network governance of urban ecosystem services: the case of Stockholm. Ecol Soc 15

European Commission (2013) Regulations establishing measures in respect of the Faroe Islands to ensure the conservation of the AtlantoScandian herring stock. Off J Eur Union L223:1-7

European Union, Norway, Faroe Islands (2015) Agreed record of conclusions of fisheries consultations between the Faroe Islands, the European Union and Norway on the management of mackerel in the northeast Atlantic for 2016. https://www.regjeringen.no

Flyvbjerg B (1998) Rationality and power: democracy in practice. University of Chicago Press, Chicago

Folke C, Pritchard L, Berkes F, Colding J, Svedin U (1998) The problem of fit between ecosystems and institutions. IHDP working paper no. 2. International. Bonn, Germany

Folke C, Hahn T, Olsson P, Norberg J (2005) Adaptive governance of social-ecological systems. Annu Rev Environ Resour 30:441-473. doi:10.1146/annurev.energy.30.050504.144511

Folke C, Pritchard Berkes F, Colding J, Svedin UL, Pritchard L, Berkes F, Colding J, Svedin U, (2007) The problem of fit between ecosystems and institions:ten years later. Ecol. Soc. 12:30

Foucault M (1980) History of sexuality. Volume 1: an introduction. Vintage Books, New York

Foucault M (2000) [1982]. The subject and power. In: Faubion JD (ed) power: essential works of Foucault 1954-1984. New Press, New York, vol 3, pp 326-348

Fraser E, Mabee W, Slaymaker O (2003) Mutual vulnerability, mutual dependence: the reflective notion between human society and the environment. Glob Environ Chang 13:137-144

Galaz V (2014) Global environmental governance, technology and politics. Edward Elgar Publishing Limited, Stockholm

Galaz, V., Olsson, P., Hahn, T., Folke, C., Svedin, U., 2008. The problem of fit among biophysical systems, environmental and resource regimes, and broader governance systems: insights and emerging challenges. In: Young, O.R., Schroeder, H., King, L.A. (Eds.), Institutions and environmental change principal findings, applications, and research frontiers

Gänsbauer A, Bechtold U, Wilfing H (2016) SoFISHticated policysocial perspectives on the fish conflict in the northeast Atlantic. Mar Policy 66:93-103

Garmestani AS, Allen CR (2015) Adaptive management of socialecological systems. Springer Netherlands, Dordrecht

Gattuso J-P, Magnan A, Bille R, Cheung WWL, Howes EL, Joos F, Allemand D, Bopp L, Cooley SR, Eakin CM, Hoegh-Guldberg O, Kelly RP, Portner H-O, Rogers AD, Baxter JM, Laffoley D, Osborn D, Rankovic A, Rochette J, Sumaila UR, Treyer S, Turley C (2015) Contrasting futures for ocean and society from different anthropogenic $\mathrm{CO}_{2}$ emissions scenarios. Science 349:45. doi:10.1126/ science.aac4722

Geertz C (1963) Agricultural involution. University of California Press, Berkeley 
George AL, Bennett A (2005) Case studies and theory development in the social sciences. MIT Press, Cambridge

Giddens A (1984) The constitution of society: outline of a theory. Polity Press, Cambridge

Goudsblom J (2001) Stof waar honger uit ontstond: over evolutie en sociale processen. Meulenhoff, Amsterdam

Haug G, Günther D, Peterson L, Sigman D, Hughen K, Aeschlimann B (2003) Climate and the collapse of Maya civilization. Science 299: $1731-1735$

Homer-Dixon TF (1991) On the threshold: environmental changes as causes of acute conflict. Int Secur 16:76-116

Homer-Dixon T (1996) Strategies for studying causation in complex ecological-political systems. J. Environ. Dev. 5:132-148. doi:10. 1177/107049659600500202

Homer-Dixon T (1999) Environment, scarcity, and violence. Princeton University Press, Princeton

Hoydal K (2014) Agreements on management and allocations of straddling stocks in the North East Atlantic: three case studies: Norwegian Spring Spawning (Atlanto-scandian) Herring, Blue Whiting (ICES Subareas I-IX, XII and XIV) and Mackerel in the North-East Atlantic

ICES (2015) ICES Advice on fishing opportunities, catch, and effort northeast Atlantic Ecoregion for 2016. Copenhagen

ICES ADVISORY COMMITTEE (2013) Report of the working group on widely distributed stocks (WGWIDE) 2013. Copenhagen

ICES ADVISORY COMMITTEE (2014a) Report of the report of the working group on widely distributed stocks (WGWIDE) 2014. Copenhagen

ICES ADVISORY COMMITTEE (2014b) Report of the benchmark workshop on pelagic stocks (WKPELA). Copenhagen

ICES ADVISORY COMMITTEE (2014c) Advice on fishing opportunities, catch, and effort Northeast Atlantic Ecoregion for 2015. Copenhagen

ICES Factsheet (2016) Mackerel http://www.ices.dk/explore-us/projects/ EURFP/EU\% 20Repository/ICES\%20FIshMap/ICES\% 20FishMap\%20species\%20factsheet-mackerel.pdf. Accessed 29 Feb 2016

Jensen F, Frost H, Thøgersen T, Andersen P, Andersen JL (2015) Game theory and fish wars: the case of the northeast Atlantic mackerel fishery. Fish Res 172:7-16

Langøy H, Nøttestad L, Skaret G, Broms C, Fernö A (2012) Overlap in distribution and diets of Atlantic mackerel (Scomber scombrus), Norwegian spring- spawning herring (Clupea harengus) and blue whiting (Micromesistius poutassou) in the Norwegian Sea during late summer. Mar Biol Res 8:442-460. doi:10.1080/17451000. 2011.642803

Lockwood SJ (1988) The mackerel. Its biology, assessment and the management of a fishery. Fishing News Books, Farnham

Mahoney J (2001) Beyond correlational analysis: recent innovations in theory and method. Sociol Forum 16:575-593

Mahoney J, Kimball E, Koivu KL (2009) The logic of historical explanation in the social sciences. Comparative Political Studies 42:114 146

Miller KA (2000) Pacific salmon fisheries: climate, information and adaptation in a conflict-ridden context

Miller KA (2007) Climate variability and tropical tuna: management challenges for highly migratory fish stocks. Mar Policy 31:56-70. doi:10.1016/j.marpol.2006.05.006

Nordic Council of Ministers (2011) The pelagic complex in the North East Atlantic Ocean challenges and possibilities in the pelagic sector-looking towards the future. Copenhagen

Norwegian Ministry of Fisheries and Coastal Affairs (2010) Ban on landings of mackerel from Faroese and Icelandic vessels [WWW Document]. URL https://www.regjeringen.no/en/aktuelt/Ban-onlandings-of-mackerel-from-Faroese-and-Icelandic-vessels/ id611793/
Nøttestad L, Utne KR, Óskarsson GJ, Jónsson SP, Arge J, Tangen Ø, Anthonypillai V, Pena H, Bernasconi M (2014a) Abundance and spatial expansion of northeast Atlantic mackerel (Scomber scombrus) according to trawl surveys in the Nordic Seas 2007 to 2013, pp 1-44

Nøttestad L, Salthaug A, Johansen GO, Utne KR, Anthonypillai V, Tangen $\varnothing$, Debes H, Mortensen E, Smith L, Ólafsdóttir A, Jacobsen JA, Jansen T, Sveinbjörnsson S, Óskarsson GJ, Jónsson S (2014b) Cruise report from the coordinated ecosystem survey (IESSNS) 2014

OECD (2011) OECD economic surveys: iceland 2011

Olsson P, Gunderson LH, Carpenter SR, Ryan P, Lebel L, Folke C, Holling CS (2006) Shooting the rapids: navigating transitions to adaptive governance of social-ecological systems. Ecol Soc 11

Olsson P, Folke C, Galaz V, Hahn T, Schultz L (2007) Enhancing the fit through adaptive co-management: creating and maintaining bridging functions for matching scales in the Kristianstads Vattenrike Biosphere Reserve, Sweden. Ecol Soc 12

Ørebech P (2013) The "lost mackerel" of the North East Atlantic - the flawed system of trilateral and bilateral decision-making. Int J Mar Coast Law 28:343-373. doi:10.1163/15718085-12341276

Óskarsson GJ, Sveinbjörnsson S, Guðmundsdóttir Á (2012) Ecological impacts of recent extension of feeding migration of NE-Atlantic mackerel into the ecosystem around Iceland. ICES CM 2012/M: 03. ICES J Mar Sci 1-25

Pauly D, Zeller D (2016) Catch reconstructions reveal that global marine fisheries catches are higher than reported and declining. Nat Commun 7. doi:10.1038/ncomms10244

Pinsky ML, Fogarty M (2012) Lagged social-ecological responses to climate and range shifts in fisheries. Clim Chang 115:883-891. doi:10.1007/s10584-012-0599-x

Polasky S, Carpenter SR, Folke C, Keeler B (2011) Decision-making under great uncertainty: environmental management in an era of global change. Trends Ecol Evol 26:398-404. doi:10.1016/j.tree. 2011.04.007

Russell B (1938) [1939]. Power: a new social analysis. Allen and Unwin, London

Ruttan VW, Hayami Y (1984) Toward a theory of induced institutional innovation. J Dev Stud 20:203-223

Scott JC (1985) Weapons of the weak: everyday forms of peasant resistance. Yale University Press, New Haven

Scott WR (2013) Institutions and organizations: ideas, interests, and identities. Sage Publications, Thousand Oaks

Seafish (2014) Management of the NEA mackerel fishery

Sherman K, Belkin I, Friedland KD, O'Reilly J (2013) Changing states of North Atlantic large marine ecosystems. Environ Dev 7:46-58. doi: 10.1016/j.envdev.2013.05.004

Stinchcombe AL (1998) Monopolistic competition as a mechanism: corporations, universities, and nation-states in competitive fields. In: Heström P, Swedberg R (eds) Social mechanisms: an analytical approach to social theory. Cambridge University Press, New York, pp 267-305

Stone-Jovicich S (2015) Probing the interfaces between the social sciences and social-ecological resilience: insights from integrative and hybrid perspectives in the social sciences. Ecol Soc 20

Sumaila UR, Cheung WW, Lam VW, Pauly D, Herrick S (2011) Climate change impacts on the biophysics and economics of world fisheries. Nat Clim Chang 1:449-456

Termeer CJAM, Dewulf A, van Lieshout M (2010) Disentangling scale approaches in governance research: comparing monocentric, multilevel, and adaptive governance. Ecol Soc 15. doi:10.1093/mp/ $\operatorname{ssn} 080$

The Government of the Faroe Islands (2014) Mackerel agreement should herald new era of fisheries cooperation in the North East Atlantic. Retrieved February 29, 2016 from http://www.fisk.fo/kunning/ 
tidindi/mackerel-agreement-should-herald-new-era-of-fisheriescooperation-in-the-north-east-atlantic/

The World Bank (2000) Adapting to climate change IV

Undercurrentnews, 2013. Greenland's strong mackerel catches see power shift further west [WWW Document]. URL http://www. undercurrentnews.com/2013/12/09/mackerel-industry-braces-forinteresting-year-on-back-of-goodgreenland-catches/. Accessed 4 June 2015

Undercurrentnews (2015) Northeast Atlantic mackerel biomass estimated at $7.7 \mathrm{~m}$ in first drop since 2007 [WWW Document]. URL https://www.undercurrentnews.com/2015/08/28/ northeast-atlantic-mackerel-biomass-estimated-at-7-7m-in-firstdrop-since-2007/

Vanderzwaag DL, Russell DA (2010) Challenges and future directions in transboundary fisheries management: concluding reflections. In: Recasting transboundary fisheries management arrangements in light of sustainability principles: Canadian and international perspectives. Martinus Nijhoff Publishers, Leiden, p 544
Walters BB, Vayda AP (2009) Event ecology, causal historical analysis, and human-environment research. Ann Assoc Am Geogr 99:534 553. doi:10.1080/00045600902931827

Weber M (1978) [1922]. Economy and society: an outline of interpretive sociology. University of California Press, Berkeley

West S (2016) Meaning and action in sustainability science: interpretive approaches for social-ecological systems research. PhD thesis. Stockholm University, Stockholm

Wilson C, Tisdell C (2003) Conflicts over natural resources and the environment: economics and security. Brisbane, Australia

Yancheva G, Nowaczyk NR, Mingram J, Dulski P, Schettler G, Negendank JFW, Liu J, Sigman DM, Peterson LC, Haug GH (2007) Influence of the intertropical convergence zone on the East Asian monsoon. Nature 445:74-77

Young OR (2002) The institutional dimensions of environmental change: fit, interplay, and scale. The MIT Press, Cambridge

Zhang DD, Brecke P, Lee HF, He Y (2007) Global climate change, war, and population decline in recent human history. PNAS 104 